\title{
THE COGNITIVE PROCESS OF DIFFERENT GENDER IN WRITING ARGUMENTATIVE TEXT
}

\author{
Surya Setiadi Tarigan \\ I Wayan Dirgeyasa \\ Rahmad Husein \\ English Aplied Linguistic Program \\ Postgraduate Program-Universitas Negeri Medan
}

Diterima Mei 2020; Disetujui Juni 2020; Dipublikasikan Agustus 2020

\begin{abstract}
The aim of this study was to know the cognitive process manner of different gender in writing argumentative text. The population of this study was grade XII of Free Methodist Senior High School Medan in 2019/2020 academic years and the sample was three males and three females. The sample was taken by snowball technique. This study was conducted by using descriptive qualitative research design of which data were the transcript of think aloud protocol and retrospective interview. In analyzing the data, this research used model of Miles and Huberman, namely data collection, data reduction, data display, and data verification. Based on the data analysis was found that male and female had difference manners in writing argumentative text. The male students generated the ideas by brainstorming, and then they outlined the thinking ideas orderly as a guide in writing. In the translating process, they tended to transform the ideas based on the generic structure of argumentative text referred to the outlines which were made before. In the process of writing they did reading and editing words and sentences have been arranged well. In the end of their writing, they tended to read their writing result to make sure. While the female students had different way with male students where in the planning process, they generated the ideas by brainstorming then, they developed the points by outlining the ideas and the ideas were improved the quality by reading and revising the ideas. In the translating process, they tended to develop their writing by structuring it based on the argumentative generic structure without reading and editing because they tended to write it fluently. In reviewing, they did reading the text to check all words and sentences. In addition, they revised the error words and sentences which were found.

Keywords: Cognitive Process, Different Gender, Writing, Argumentative Text
\end{abstract}

How to Cite: Setiadi Tarigan, Surya. (2020). The Cognitive Process of Different Gender in Writing Argumentative Text. Jurnal Linguistik Terapan-Pascasarjana 
Unimed. 17 (2) : 194- 204.

\section{ISSN: 2407 - 7410}

\section{INTRODUCTION}

In the process of teaching and learning English, writing is one of productive skill besides speaking. This subject is the most difficult and complicated language skill to be learned by the students in every level of education. The students must have ability in organizing ideas, produce meaningful and structured sentences. If the students do not have those abilities they will face problems in producing a good writing. In writing process, there are three stages should be done by students such as planning, translating, and reviewing and all of them active the cognitive process. Cognitive process is the act or process of knowing in the broadest sense; specifically an intellectual process by which knowledge is gained from perception or ideas. There are some writing types which force to active cognitive process in mind in order to pour the ideas logically; one of them is argumentative writing. Chase (2011) mention, argumentative text requires the writer to embrace a particular point of view and try to convince the readers in order to have the same perspective. The writers also have to arise the problems and attempt to map language onto his or her own thoughts and feelings as well as the expectations of the reader.

One of the socio-cultural factors shaped by learners in the process of learning a language including writing is gender. Gender is categorized in male and female. Each of them has different perceptions about something so they also have different way in writing idea or opinion. Male and female are believed to have different language in pouring the ideas based on their perception or experience. It can be seen from the researcher everyday observation to his students. The researcher found in the students' assignment that male writes only a few line and it jumps to the point and it was difficult for the male students to accomplish their writing task. Most of them would rather copy from other sources than write themselves or only have fewer words to write whenever they are asked to write an essay. In the process of writing, they tend to complete their writing without planning and reviewing. While the females always do the task well even it's not all finish it. They tend to remember again what they have stored in their mind and tend to make the outline first before writing. After finishing, some of them reread and check their writing word by word. The female students tends to be careful in checking their writing again because they want to make sure the result of their writing is good and perfect. 
Pease (2003) stated that boys in schools are viewed as "under-achievement" and the teachers have higher expectations for female. The female are said doing miles better than the male in exams. In addition, he investigated that female students used writing strategies better and their general strategies and writing habits were different from the ones used by male students. Female student writers received significantly higher writing strategy employment scores than that of male students.

Besides all those, the researcher has interviewed one male and one female students

Researcher $\quad$ Zril, bagaimana kamu membuat
tulisan argumentative ini?
Zril, how did you make this
argumentative writing?

Student $\quad$ : Apa yang kutau langsung kutulis

sir, setelah siap langsung kukasi

sama sir.

I wrote the writing that I knew sir,

I gave it directly to you after

finishing.

(FMI/RI-M/Friday, May 05 ${ }^{\text {th }}$ 2019)

From the interviewing above, the researcher concluded that the male student wrote the argumentative writing itself without planning because the student developed his writing without retrieving the information of his long term memory. The student didn't make a draft or outline what he had to write so he faced a difficulty in developing the issue in writing. After finishing, that male student gave the writing directly without rereading or editing again so the researcher found there were some bad grammar in the writing so it made the reader confused in understanding his writing. The cognitive process happened only in translating stage.

Researcher $\quad$ Deang, bagaimna kamu
membuatulisan argumentative ini?
Deang, how did you make this
argumentative writing?


tadi. Setelah siap kucek lagi sir

soalnya grammar saya berantakan

jadi untuk memastikannya.

Firstly, I remembered what the importance of learning English. Then, I drew the outline to make it easily. After that, I wrote sir. It's difficult to combine one sentence to others. After finishing, I checked it again to make sure because my grammar was not really good. (FMI/RI-F/Friday, May $05^{\text {th }}$ 2019)

From the writing above, it could be seen that the female student had a good ability in writing argumentative text because she could generate the ideas and developed her opinions in the writing. There were three cognitive processes happened in her mind. The first was generating an idea which was to retrieve information relevant to the writing task from longterm memory. The second was translating where she developed her ideas to be a good argumentative writing. And the last was reviewing where she made sure by reread and editing again the text.

The preliminary data showed that there were differences the students' cognitive process in writing between male and female. Male student tended to complete the writing soon without organizing the ideas, drawing outline. He developed the ideas directly so he faced silent thinking in a long time for several times. In constructing sentences by sentences, the male student still made some wrong grammars. In the writing process, the male students just activated his cognitive process in translating. Meanwhile, the female student wrote the draft of the issue firstly. She called the information that she stored in her memory first. Then, In developing the ideas, she wrote the ideas well and looked fluently but she realized that she was still weak in constructing the sentences by using a good grammar and appropriate word. Female student did planning, translating and reviewing by rereading her writing.

The previous research about cognitive process in writing had been conducted by Sapitri (2017) which entitled Cognitive Process of the Students in Writing Argumentative Text. As the result, the cognitive processes of the students from the two majors were different in planning, translating and reviewing. In Planning, the students of Natural Science did the planning before writing such as gathering ideas, organizing and jot down their ideas while the social science students did not do planning before writing. In gathering their ideas or organize the ideas, they seemed do not have an effort. In translating, the science students are less in translating in order to get the meaning while the social science students; they are more often in translating in order to get the meaning. In reviewing, the science students tend to read, edit their texts which has been written down in order to evaluate the text while the social science 
did not do the reviewing. The cognitive processes of the students were different because they have different ability in the proficiency of writing, vocabulary and discourse comprehension.

So, based on the preliminary data and the results of the previous researches shown above, the researcher was interested to do the research about "The cognitive process of different gender in writing argumentative text". It's a different phenomenon because no one conducted the research like that. The researcher wanted to know how the cognitive process was occurred in male and female argumentative writing.

This research had a contribution as theoretically to enrich the knowledge of psycholinguistic especially in cognitive process of different gender in writing argumentative text. Then, practically this research is expected useful as a reference for other researchers who are interested in conducting researchers or any further studies in psycholinguistics to apply cognitive process of different gender in writing argumentative text

\section{REVIEW OF LITERATURE}

\section{A. Cognitive Process in Writing}

Cognition is mind or idea in a form of single, group, or even organization. Cognition is a process which consists of three processes called as psychological process; (1) Perception, (2) learning, and (3) reasoning. The general writing process is composed of three processes that allow transforming domain knowledge in a linguistic product (with their sub-processes and/or associated operations) and a process of control. These processes are

\section{Planning}

Gregg (1992) argues that planning is defined as the process of taking information from the task environment and the long term memory and to use it to set goals and to establish a writing plan to guide the production of a text that will meet those goals. It has three sub-processes, they are generating ideas, organizing, and setting goal. First, generating ideas are the process in retrieving relevant information from long-term memory. Second, organizing process allows the writer to identify categories, to search for subordinate ideas which develop a current topic, and to search for super ordinate ideas which include or subsume the current topic. The last, goal-setting process is to identify and store such criteria for later use in editing.

\section{Translating}


Moreover, Gregg (1992) stated that translating process is to take material from memory under the guidance of the writing plan and to transform it into the acceptable written English sentences. This is essentially the process of putting, developing, transforming ideas and plans into visible language. The process of translating requires the writer to juggle all the special demands of written English.

\section{Reviewing}

The function of the reviewing process is to improve the quality of the written text. It consists of two sub processes: reading and editing. He then said that reading is considered as the phase in which the writer read his/her writing and find some errors or incorrect sentences. Its purpose is to detect and correct violations in writing conventions and inaccuracies of meaning and to evaluate materials with respect to the writing goals. While editing is to detect and correct weaknesses in the text with respect to language conventions and accuracy of meaning, and by evaluating the extent to which the text accomplishes the writer's goal.

\section{B. Gender}

It is very important to clarify the distinction between sex and gender. Sex marks an essentially biological distinction between women and men that may be based upon their anatomical, physiological, or chromosomal properties. While gender marks a socio-cultural distinction between men and women on the basis of the traits and behavior that are conventionally regarded as characteristic of and appropriate to the two groups of people. Douglas (2007) mentioned that gender is one's identification as male / man / masculine or female/woman/feminine on the basis of somatic and behavioral criteria. It means that someone can be said as male or female from his or her typical body, appearance, and sexual characteristic. Besides, the way someone behaves and performs might determine whether someone is male or female.

The differences between sex and gender can be seen in their roles. The gender roles are may differ from society to society, can change with history as example in the past, female just stayed at home for finishing the housework but now woman can be a career, can be performed by both of sexes, they are socially, culturally determined. While sex roles are same in all societies: they are universal as example it is only women who give birth to children all over the world, never change with history, can be performed by only one the sexes and they are biologically determined.

From the explanation above can be concluded that a sex role is a function or role which a male or female assumes because of the basic physiological or anatomical differences between the sexes. It is a biologically determined role which can be performed by only one of the sexes for example women give birth to children while men 
make women pregnant. These roles are not exchangeable because they are biologically determined. While Gender roles for men and women vary greatly from one culture to another, and from one social group to another within the same culture. race, class, economic circumstances, age-all of these influence what is considered appropriate for men and women. As culture is dynamic, and socio-economic conditions change over time, so gender patterns change with them.

\section{Argumentative Writing}

Dirgeyasa (2018) states that argumentative or persuasive essay is a kind of essay expressing opinion about controversial issue. As the writer, you must take a position and persuade the reader to agree with your opinion by using strong logical reasons to support your argument. In addition, it is a writing genre where the student establishes a position on given or chosen topic and then uses evidence to persuade the audience to see things from his/her point of view. In addition, it is defined as the sequence of interlinked claims and reasons that, between them; establish content and force of the position for which a particular speaker is arguing. Every argument is composed of obligatory elements such as claim and data and secondary elements, such as counterargument, and rebuttal

It is generally known that a good argumentative essay demonstrates not only why the writer's opinion is correct, but also why the opposing view is incorrect. To provide the writer's opinion is correct and convincing, there are some elements that are needed when writing argumentation essay.

a. Position is the first and most important element in an argumentative essay or what side the author is on.

b. Reason why the writer believes the way he or she does. By offering these reasons, the writer opinion is more convincing.

c. Evidence is the facts, statistics, quotation, and claims from experts (quotations) in certain topic's field or issue are used to support reason.

d. Counterarguments also used to in which the other side's arguments are not correct.

Based on the above elaboration, it can be concluded that the core component of argumentation is clearly the development of a position, which can also be regarded as equivalent to the development of an argument. Another component is the presentation of the position through the logical arrangement of the propositions that build this position which is connected series of statement and the sequence of interlinked claims and reasons. 


\section{RESEARCH METHODOLOGY}

This research was conducted by using descriptive qualitative design since this research did not give any treatment to the text meanwhile the data is natural setting and the researcher is the key instrument. The population of this research was grade XII and the sample was three males and three females of XII grade students of Free Methodist in the 2019/2020 academic years which is located on J1. Sekolah No 33 Medan Helvetia.

The source of data was taken by snowball technique where that was started from a small sample into the big one. It meant that only one or two subjects could be found initially by identifying potential subjects in the population and then asked those subjects to recruit others. These steps were repeated until the needed sample size was found. This sampling technique might help the researcher discovered characteristics about a population that he wasn't aware existed. The techniques in collecting data of this research used observation and interview sheet with recorder as the instrument to record the students' think aloud protocol and interviewing result after the students finished their think aloud protocol. This research used the interactive Model Technique of Miles and Huberman in analyzing the data which are consisted on data reduction/condensation, data display, and conclusion drawing / verification.

\section{DISCUSSION}

The research question of this study deals with the cognitive process ways of different gender occurred in writing argumentative text. As stated that writing is not easy skill for students due to the process of writing itself is influenced by cognitive activities or mental process. Dealing with the theory of [7], the way of cognitive process in writing can be seen when the writers write that composition in the stages of writing such as planning, translating, and reviewing.

Based on the data of this study, male and female had different way of the cognitive process in writing argumentative text. The cognitive process way of male student that occurred in writing argumentative text are: (1) Planning. In the planning process, the male students tended to generate their ideas of their long term memory by brainstorming. It was done by recalling their knowledge about the topic given and storing the writing plans in their minds. All the ideas were outlined based on the generic structure of argumentative text and read it then (2) Translating. In the translating process, all the ideas which have been recalled in their mind were written in the Indonesian version first and then changed it into English version. Those ideas were structured based on the generic structure of the argumentative text such as thesis, arguments, and the conclusion. They structured it due to the knowledge about 
the concept of argumentative before. In developing ideas, there were some problems they faced such as grammar, less of vocabulary and selection diction word so there were some corrections in their writing.

Meanwhile, the cognitive process way of female in writing argumentative text that occurred are in the three stages: (1) Planning. In the planning stage, female tended to generate their ideas of their long term memory which are such as knowledge of the topic and stored writing plans by brainstorming. The brainstorming results were written in a scratch paper as the framework of the story or outline for guiding them to write their writing easily. Then, the outlines were read and revised to improve the outline itself. (2) Translating. In the translating process, the female students developed the outline or framework story become the writing needed based on the title given "Should senior high school students master English?. They wrote the writing based on the knowledge they kept in their mind about argumentative where it has a generic structure thesis, arguments and conclusion. In addition, they focused on its purpose to persuade or to convince the readers so they have same opinion or perception with the writer. And the last is (3) Reviewing. In this process, the female students tended to active cognitive process by reading and editing the writing to make sure all the sentences have a good structure and correct.

It is not supported by Gregg (1992) who found that the cognitive process of male student that occurred in writing are: (1) Selecting the title means decided and chose what the title that regarded the student as the interesting one to write. The process of selecting the title of the text is starting by imagine and remember the story which supported by their long term memory about that story. (2) Organizing the ideas means putting the ideas into a logical order or providing the informant the key words that they have been structured on. (3) Translating the text means change the source language into a target language. The process of translating the text is starting by changing the Indonesian language into English language.

Meanwhile, the cognitive process of female students that occurred in writing are: (1) Organizing the ideas means putting the ideas into a logical order or providing the informant the key words that they have been structured on their mind. The process of making story framework is starting by make the text into some paragraph and each paragraph has the main ideas which tell the story consists of the opening, the content, and the ending. (2) Developing the ideas means that the informant elaborate or expand the ideas of the text in detail so that the informant can continue to write the whole ideas completely and the writing will be comprehensible to the reader. The process of writing the text is starting by develope the sentence and make it into a good structure which written on the paper. (3) Reviewing the text means re-read and revised 
the texts that already finish making sure that the text of writing is correct. The process of reviewing the text is starting by re-read the story from the beginning until the end then checking the errors and revising it.

The cognitive process manner of male and female is difference. The way of male students was simpler than the female because they wrote it as informational and it was proved from the stages which the male did in writing. As the theory of [8], male's writing is simpler than female because it is just informational while the females' writing focused to create the relationship between the writer and reader so they activated their all cognitive process in writing argumentative text. Carmata's theory stated too that females are very adept at recalling information too. It was proved that in the planning process, the females' students have a good generating the idea then organizing the ideas got. In addition, the ideas were read and revised to improve the quality of the essay.

\section{CONCLUSION}

After analyzing the data, the conclusions can be stated as the following: The cognitive process in writing of different gender had a different and similarity. The differences occurred in the first step and in the last step of writing process. The male students tended to generate the ideas from the long term memory by the knowledge of the topic and stored writing plans through brainstorming and the result of that brainstorming were organized by outlining based on the generic structure. In developing ideas, they wrote the ideas by following the generic structure such as thesis, argument, and conclusion. In the process of writing they did reading and editing words and sentences have been arranged well. In the end of their writing, they tended to read their writing result to make sure. While the female students had different way with male students where in the planning process, they generated the ideas by brainstorming then, they developed the points by outlining the ideas and the ideas were improve the quality by reading and revising the ideas. In the translating process, they tended to develop their writing by structuring it based on the argumentative generic structure without reading and editing because they tended to write it fluently. In reviewing, they did reading the text to check all words and sentences. In addition, they revised the error words and sentences which were found.

\section{REFERENCES}


Chase, B J. (2011). An Analysis of the Argumentative Writing Skills of Academically Underprepared College Students. Unpublished Disertation, Columbia University.

Pease, A. (2003). Why Men Don't Listen and Women Can't Read Maps. London: Orion Publishing Group.

Sapitri, R. (2017). Cognitive Process of Students in Writing Argumentative Text. Universitas Muslim Nusantara Al-washliyah. Journal of English Teaching and Research.

Gregg W, L \& Steinberg R, E. (1992).Cognitive Process in Writing. United State of America.

Douglas, F. M. (2007). Encyclopedia of Sex and Gender. Detroit: The Gale Group.

Dirgeyasa, I. (2018). Effective Academic Writing: A breakthrough of Writing Essay, Paraphrasing, and Summarizing. Yogyakarta: PUSSIS-UNIMED.

Flower, L and J.R.Hayes (1981) Cognitive Process Theory of Writing. College Composition and Communication. Vol. 32, No. 4.

Camarata, S and W. Reynold (2015). Sex Differences in Processing Speed:Developmental Effect in Males and Females. Accessed on May 20, 2019, from (http://dx.doi.org/10.1016/j.intell.12.001). 